\title{
An empirical research on strategic management: a research on SME managers*
}

\author{
Oğuzhan Aytar ${ }^{1}$ (D) Ali Aydoğdu Selamet ${ }^{2}$ (D) \\ 1 Assoc. Prof., Karamanoğlu Mehmetbey University, Faculty of Economics and Administrative Sciences, Karaman, TURKEY E-mail: oguzhanaytar@hotmail.com \\ 2 Karamanoğlu Mehmetbey University, Faculty of Economics and Administrative Sciences, Karaman, TURKEY E-mail: aydogduselamet@hotmail.com
}

\begin{abstract}
Small and Medium Enterprises (SMEs) are the main economic actors in terms of the healthy development of the countries' economies and the increase of social welfare level. The continuity and success of these enterprises also have some social effects. Socially, effective use of capital, employment creation potential, support for the development and effective meeting of customer demands are among its most important and strategic features. The aim of this study is to determine the level of knowledge of SME managers in Karaman province about strategic management discipline tools and to reveal their views on strategic management. Within the scope of the research, SMEs in the Karaman Organized Industrial Zone were determined according to the complete count method and a questionnaire study was applied. The differences in opinion and knowledge level according to the demographic variables of the participants were analyzed. According to the results of the research, there is a significant positive relationship between education level and strategic management awareness.
\end{abstract}

Keywords: Strategic Management, SME, Managers, Karaman OIZ

JEL codes: M1, M13, L21

Corresponding Author/ Sorumlu Yazar:

Oğuzhan Aytar

E-mail: oguzhanaytar@hotmail.com
Bu derginin içeriği Creative Commons Attribution-NonCommercial 4.0 Uluslararası Lisansı altında lisanslanmıştır.

Content of this journal is licensed under a Creative Commons Attribution-NonCommercial 4.0 International License. 


\section{INTRODUCTION}

It is a general situation that Small and Medium Enterprises (SMEs) are examined and subject to economic policies due to the importance they have on country economies. This situation also steers the development of the global economy around the world (Mecek, 2020:49). Although they have a very important position in the economies of the country, many SMEs end their existence by not being able to struggle with the global competition due to internal and external business problems. For these reasons, SMEs need a more dynamic and modern management and appropriate management, tools and techniques (Kaya, 2014:27; Dauda et al, 2010:97).

Although they are located all over the world and have some unique features, SMEs are defined differently by both different countries and institutions within countries (Mecek, 2020:30). Definitions made for SMEs vary according to the economic situation and sectoral volume of the countries. In the literature, SME is defined as economic enterprises that use less capital in their activities, work generally with manual labor, make quick decisions, work with low-cost management activities and perform cheap production (Kiziltan \& Sarıhasan, 2016:29). Due to the advantages offered by SMEs, all countries, especially developed countries, are making efforts for the establishment, development and growth of SMEs (Şamiloğlu \& Uygun, 2012:105).

SMEs create personnel employment with low investment costs, they can more easily adapt to changes in customers' demands and various requests of customers. SMEs are in a position to adapt to continuous changes in technology, to stabilize regional development, to minimize income inequality, to direct individual savings, and to support and complement large industrial enterprises (Emecen \& Çiçek, 2016:144; Cansiz, 2008:4).

There are some problems, especially financial problems, among the problems faced by SMEs. These problems can be grouped under the headings of financial, technological, managerial, production, marketing, competition and human resources. Technological developments in particular contain great threats as well as presenting new opportunities (Luecke, 2005:12). These problems prevent SMEs from reaching their goals. Although small and medium sized enterprises provide great benefits to the economy of the country, they are faced with many problems especially in newly developing economies (Korkmaz, 2003:238). Within the scope of the study, the extent to which the strategic management discipline, which has the potential to positively affect the continuity of SMEs, is known by SME managers and their opinions on strategic management are examined.

\section{STRATEGIC MANAGEMENT}

When the literature is examined, the concept of strategic management is a concept that started to be used in the business and management discipline in the 20th century. At that time, there was no consensus on its definition. It is seen that the concept emerges from the combination of strategy and management expressions (Eren, 2009:16).

Strategic management is the efficient use of production resources (human resources, natural resources, capital, raw materials, machinery, etc.) to reach the goals and objectives of the enterprises. Strategic management is the management of businesses that will survive in the long term, provide a competitive advantage in the business and can bring profit above average, not the daily and ordinary business management of the enterprises. For this, strategic management should make the life of businesses long-term and focus on issues that will provide competitive advantage (Özbozkurt, 2019:68; Ülgen \& Mirze, 2014:28).

The rapidly changing environment and dynamic environmental conditions make the strategic management discipline one of the most important concepts affecting the future of businesses today (Schmuck, 2020:46). Therefore, it is important to examine the literature related to this concept. The concept of strategy, which has existed for centuries and has become very important recently, has taken its place in our lives as an indispensable element of our lives today. The strategy is a concept that we encounter in every aspect of our lives, in economy, politics, education, business, management, competition and even entertainment games. Looking at the etymology of the concept of strategy, it is based on two sources in the literature. The first of these two sources is related to the word stratum, which means road, line and bed in Latin. It is stated that the second one is related to the name of the former Greek General Strategos. The Greeks used the concept of strategy to indicate the general's artistic view and level of knowledge (Eren, 2002:1). Looking at the concept of strategy in business and management, it is seen that it started to be used in the second period of the 20th century. Here, 
strategy means to regulate relations with the business and the environment and to use its resources in the most efficient way in order to gain superiority and competitive advantage against its competitors (Dinçer, 2007:17).

Strategic management commits businesses to renew themselves against changing conditions, to reveal their differences in the market compared to their competitors, to develop the weaknesses of the business and to take measures, to innovate in the areas where the business is superior. The aim of strategic management is to increase the productivity and profitability of the business in the future. Strategic management is to create a vision for the future of the business. Strategic management ensures that the enterprise forms a healthy whole with its environment. For this reason, strategic management is seen as an important tool for the business to be successful in its activities and to have a long life span (Gönen, 2013:11).

Strategic management includes the features of general management but also has its own characteristics. Strategic management is a system that follows the external environment and is sensitive to the environment in terms of all management levels of the enterprise (Güvercin, 2008:25).

\section{THE IMPORTANCE OF STRATEGIC MANAGEMENT FOR SMES}

SMEs instill entrepreneurship spirit in individuals in all countries and contribute to the development of entrepreneurship. Although the concept of SME has some differences according to countries and individuals, there are common points among these definitions in terms of quality and quantity (Mecek, 2020: 49). They have the flexibility to adapt to the changes in the demands and demands of the customers by creating more product variety with less investment in all countries' economies (Aragón-sánchez \& Sánchez-marín, 2005:288). Due to these features, SMEs are less affected by the economic fluctuations that will occur (Çatal, 2007:343). SMEs have vital importance for the economy of many countries by creating the infrastructure of large enterprises and they add vitality to the economy. Producing products and services produced by large enterprises, SMEs force large enterprises to compete and provide support to large enterprises by producing products and semifinished products that large enterprises use while producing products and services. On the other hand, SMEs are a social tool to reduce poverty and inequality between regions. Therefore, SMEs have become the most important factor in the economic development of developed and developing countries today (Kalayc1, 2017:240).

SMEs contribute not only to the economy but also to the social lives of countries. Since SMEs spread over a large area in the countries, they are a very important economic unit in minimizing the interregional development level differences, spreading the property of the society to large areas, adding vitality to the democratic life of the society and making this vitality permanent. Meeting the daily and continuous demands and requests of customers and consumers, being able to establish relationships with all members of the society, actively and rapidly adapting to the changes in the demands and desires of customers show the stability of SMEs in economic and social life (Çatal, 2007:337).

Strategic management first reveals the reasons for the existence of the business. The business determines the goals it wants to achieve in this direction. Strategic management ensures the efficient distribution of resources in the enterprise and ensures that the employees of the enterprise become aware of and internalize what they are working for. For SMEs, the strategic management process is seen as both the main reference source and a critical success factor in the success of strategies (Aytar, 2019: 3488). Strategic management awareness provides direction for the enterprise to achieve its purpose in an environment where uncertainties are high, which is constantly changing and which has high risk. For this reason, strategic management provides the manager with creative and intuitive decision-making methods as it is an approach to compiling qualitative and quantitative information and making healthy decisions under uncertain conditions (Barbosa et al, 2020:2; Williams et.al, 2020:2379). Strategic management offers the company the opportunity to evaluate the environment, foresee the future and to internationalize.

\section{METHODOLOGY}

Quantitative research method was adopted in the study, in which numerical data and statistical analysis were used. In this context purpose and importance of the research and scope of the research and data collection tools used are presented.

\subsection{Purpose and Importance of the Research}

Strategic management is a process that has the 
potential to significantly affect continuity for all organizations. The purpose of this research is to determine the knowledge level of the SME owners or managers operating in the Karaman Organized Industrial Zone (OIZ) about strategic management, their strategic management awareness, their strategic management perception level, which of the strategic management techniques they use and how strategic decisions are made in the enterprise. Strategic management knowledge, application and awareness levels of enterprises considered within the scope of SMEs are especially important. The potential of SMEs to use methods and tools that will positively affect their long-term perception and continuity will make very important contributions to the development of their environment. Within the scope of the research, the answer was sought for the following question: Do the participants' level of knowledge about strategic management tools differ significantly in terms of variables such as strategic management, competition, sources of information and participation in decisionmaking statements, gender, age and educational status?

\subsection{Scope of the Research and Data Collection Tool}

The research was conducted on Karaman OIZ SMEs using the complete count method. In the light of the data obtained from Karaman OIZ Directorate, all SMEs operating in Karaman OIZ were reached. The questionnaire technique has been adopted as data collection method. The questionnaire scale created consists of four parts. The first part includes demographic information about the participants, the second part includes strategic management tools, and the third and fourth parts include five-point Likertscale expressions about strategic management, the scale consists of 44 questions in total. While creating the questionnaire scale, the studies of Sucu (2010), Kılcı (2013), Gönen (2013), Kaya (2014), Kayar Çelik and Aytar (2019) were used. Cronbach - Alpha test was used to test the reliability of the scale. The alpha value for the expressions directed according to the test results was found to be 0.938 . In the research, representatives of 96 enterprises evaluated within the scope of SMEs among 130 enterprises actively operating in Karaman OIZ were interviewed. In this context, 109 questionnaires conducted with owners and / or managers of 96 enterprises were evaluated. Both the owners and senior managers of 13 businesses were reached.

\section{FINDINGS}

The research findings reached as a result of the analysis of the data obtained, shared in this section. In this context demographic findings, averages of the knowledge levels and opinion and findings on attitude differences have been shared.

\subsection{Demographic Characteristics}

When Table 1 is examined, it is seen that $86.2 \%$ of the participants are male, $13.8 \%$ are female, $11 \%$ of the participants have associate degree graduates and $47.7 \%$ have bachelor's degree. Therefore, it is seen that more than half of the participants have had a university education. It is a striking finding that more than half of the SME enterprises covered by the research have university graduates in managerial and ownership positions. 23.9\% of these managers or owners are in the $36-40$ age group.

Table 1. Demographic Findings of Participants

\begin{tabular}{|c|c|c|c|c|c|}
\hline Sex & Number & Percent & Age & Number & Percent \\
\hline Male & 94 & 86.2 & $20-25$ & 13 & 11.9 \\
\hline Female & 15 & 13.8 & $26-30$ & 18 & 16.5 \\
\hline $\begin{array}{l}\text { Educational } \\
\text { Status }\end{array}$ & & & $31-35$ & 22 & 20.2 \\
\hline $\begin{array}{l}\text { Primary } \\
\text { Education }\end{array}$ & 11 & 10.1 & $36-40$ & 26 & 23.9 \\
\hline $\begin{array}{l}\text { Secondary } \\
\text { Education }\end{array}$ & 3 & 2.8 & $41-45$ & 12 & 11.0 \\
\hline $\begin{array}{l}\text { High } \\
\text { School }\end{array}$ & 20 & 18.3 & $46-50$ & 9 & 8.3 \\
\hline $\begin{array}{l}\text { Associate } \\
\text { Degree }\end{array}$ & 12 & 11.0 & $51-55$ & 6 & 5.5 \\
\hline $\begin{array}{l}\text { Bachelor's } \\
\text { Degree }\end{array}$ & 52 & 47.7 & $56-60$ & 3 & 2.8 \\
\hline $\begin{array}{l}\text { Master's } \\
\text { Degree }\end{array}$ & 11 & 10.1 & & & \\
\hline $\begin{array}{l}\text { Employment } \\
\text { in the Business }\end{array}$ & & & $\begin{array}{l}\text { Sectoral } \\
\text { Distribution }\end{array}$ & & \\
\hline $1-9$ & 37 & 33.9 & Textile & 2 & 1.8 \\
\hline $10-49$ & 42 & 38.5 & Food & 26 & 23.9 \\
\hline $50-250$ & 30 & 27.5 & Furniture & 5 & 4.6 \\
\hline $\begin{array}{l}\text { Duration of } \\
\text { Employment }\end{array}$ & & & Construction & 12 & 11.0 \\
\hline $0-2$ & 7 & 6.4 & Machinery & 27 & 24.8 \\
\hline $3-6$ & 29 & 26.6 & Other & 37 & 33.9 \\
\hline $7-10$ & 16 & 14.7 & & & \\
\hline $\begin{array}{l}11 \text { years } \\
\text { and more }\end{array}$ & 57 & 52.3 & & & \\
\hline
\end{tabular}

$38.5 \%$ of the SMEs in Karaman OIZ which have the highest rate of employees have employees in the range of $10-49.24 .8 \%$ of these enterprises operate in machinery, $23.9 \%$ in food, $11 \%$ in construction sectors. $52.3 \%$ of SMEs in Karaman OIZ have a working period of more than ten years. 


\subsection{Knowledge Level and Opinion Average of the Participants}

When Table 2, which includes the opinions of the participants on strategic management tools, is examined, it is seen that the participants have knowledge about scenario analysis the least (3.22) and about the risk analysis highest (4.01). Managers attach importance to gain-loss assessment in managerial decisions. However, it is a striking result that SWOT analysis, which has a very frequent application example in the strategic management discipline, has a low level of participation. The high level of knowledge on risk analysis is followed by basic ability. It is seen that the cost benefit analysis method is one of the subjects that managers have knowledge about, with a high participation level of 3.94.

\section{Table 2. Knowledge Levels of Participants on Strategic Management Tools}

\begin{tabular}{|l|l|l|}
\hline Knowledge Level & Average & Std. Deviation \\
\hline Tools & 3.77 & 0.846 \\
\hline Strategic Plan & 3.66 & 0.983 \\
\hline Strategic Awareness & 3.81 & 0.995 \\
\hline Main Component & 3.98 & 0.933 \\
\hline Basic Skill & 3.25 & 1.402 \\
\hline SWOT Analysis & 3.23 & 1.086 \\
\hline Portfolio Analysis & 3.94 & 0.974 \\
\hline Benefit-Cost Analysis & 4.01 & 0.918 \\
\hline Risk Analysis & 3.87 & 1.010 \\
\hline $\begin{array}{l}\text { Supply Chain } \\
\text { Management }\end{array}$ & 3.61 & 1.097 \\
\hline Benchmarking & 3.76 & 0.952 \\
\hline $\begin{array}{l}\text { Total Quality } \\
\text { Management }\end{array}$ & 3.63 & 0.889 \\
\hline E-Trade & 3.22 & 1.075 \\
\hline Scenario Analysis & 3.53 & 1.005 \\
\hline Outsourcing & &
\end{tabular}

When Table 3 is examined, it is seen that the highest level of participation of managers or owners in statements about strategic management is with the statement "Strategic management is necessary for the future of the enterprise. It is a positive result for SME managers that the managers or owners associate the strategic management process with the future and this statement has the highest average participation. The statement in which the participants associate the strategic management process with having strategic awareness is one of the statements with the highest participation average of 4.35. When Table 3 is examined in general, it is seen that the participants show a high level of participation in the statements about strategic management.

\section{Table 3. Averages of Participants' Opinions on Strategic Management}

Average Std.

\begin{tabular}{|l|l|l|}
\hline Average & $\begin{array}{l}\text { Std. } \\
\text { Deviation }\end{array}$ \\
\hline
\end{tabular}

Strategic Management Reveals the strengths and weaknesses of the business.

Strategic management understanding

increases the efficiency and productivity of the enterprise.

Strategic management enables the

development of a shared vision in the business.

Strategic management offers options for

the short-, medium- and long-term solution to business problems.

Strategic management creates solid and defensible foundations for decision making

in the business.

Strategic management strengthens the understanding of strategic thinking and strategy development in the business.

Strategic management facilitates the

achievement of the main objectives of the business

Strategic management ensures that business needs are determined.

Strategic management strengthens the

planning understanding in the business.

Strategic management ensures efficient use

of business resources.

Strategic management provides

opportunity and threat assessment of the enterprise.

Strategic management facilitates the

adaptation of the business to changing conditions.

Strategic management improves businessenvironment cooperation.

Strategic management strengthens the stakeholder perception of the business.

Strategic management leads to systematic

information gathering about determining

the priorities in the business.

Strategic management removes the uncertainties that the business will encounter.

Strategic management strengthens

the main competitor perception of the

business.

Strategic management ensures that the threats that the enterprise encounters / may encounter are identified.

Strategic management ensures that the current situation of the enterprise is compared with the targeted situation.

Strategic management ensures that the enterprise is prepared for innovations and change.

Strategic management is essential for the future of the business.

Strategic management process is a process that starts with having strategic awareness.

While determining our business strategy, the activities of competitors are examined.

Strategic management is only necessary for large businesses.

\begin{tabular}{|c|c|}
\hline 4.24 & 0.637 \\
\hline 4.31 & 0.662 \\
\hline 4.25 & 0.669 \\
\hline 4.22 & 0.774 \\
\hline 4.17 & 0.705 \\
\hline 4.19 & 0.799 \\
\hline 4.17 & 0.674 \\
\hline 4.18 & 0.760 \\
\hline 4.30 & 0.601 \\
\hline 4.18 & 0.722 \\
\hline 4.25 & 0.696 \\
\hline 4.09 & 0.800 \\
\hline 3.90 & 0.793 \\
\hline 3.83 & 0.848 \\
\hline 4.16 & 0.683 \\
\hline 4.14 & 0.833 \\
\hline 4.12 & 0.754 \\
\hline 4.28 & 0.756 \\
\hline 4.28 & 0.668 \\
\hline 4.27 & 0.676 \\
\hline 4.42 & 0.724 \\
\hline 4.35 & 0.644 \\
\hline 3.87 & 0.840 \\
\hline 2.16 & 1.172 \\
\hline
\end{tabular}


When Table 4. is examined, the opinion that competition between enterprises will increase innovation efficiency in terms of enterprises has the highest participation average. Managers are of the opinion that strategic management discipline is an effective issue in developing innovations in terms of competition. It is observed that managers cite common customers as sources of information, as well as the internet, magazines and newspapers, which have the highest level of participation among the methods of accessing competing business strategies. In today's business world, it is seen that classical information acquisition methods are also valid along with current information communication tools. In terms of expression how strategic decisions are made, it is seen that the lowest participation by the managers is in the intuitive methods (2.34), and the highest participation is in the analytical perspective where resources and capabilities (4.19) are taken into account.

Table 4. Average Opinion of Participants Regarding Competition, Reaching Competitor Strategies and Making Strategic Decisions

\begin{tabular}{|c|c|}
\hline STATEMENTS & Average \\
\hline \multicolumn{2}{|c|}{$\begin{array}{l}\text { Perspectives of Participants Regarding Competition } \\
\text { Between Businesses }\end{array}$} \\
\hline It provides social benefits. & 3.94 \\
\hline It provides economic benefits. & 4.14 \\
\hline It provides production efficiency. & 4.32 \\
\hline $\begin{array}{l}\text { It provides efficiency in resource } \\
\text { distribution. }\end{array}$ & 3.93 \\
\hline It provides innovation efficiency. & 4.39 \\
\hline \multicolumn{2}{|c|}{$\begin{array}{l}\text { Perspectives of Participants on the Statement "Which } \\
\text { Source Do You Use to Acquire Competitor Business } \\
\text { Strategies" }\end{array}$} \\
\hline From other enterprises & 3.52 \\
\hline From common suppliers & 3.75 \\
\hline Internet, magazines and newspapers & 3.86 \\
\hline From common customers & 3.85 \\
\hline From R\&D enterprises & 3.75 \\
\hline From meetings and conferences & 3.49 \\
\hline $\begin{array}{l}\text { Participants' Perspectives on Strategic } \\
\text { Making }\end{array}$ & Decision \\
\hline $\begin{array}{l}\text { Decisions are taken to evaluate new } \\
\text { opportunities. }\end{array}$ & 4.15 \\
\hline $\begin{array}{l}\text { Decisions are taken according to customer } \\
\text { requests. }\end{array}$ & 4.09 \\
\hline Decisions are made by the business owner. & 3.70 \\
\hline $\begin{array}{l}\text { Decisions are taken in line with the } \\
\text { resources and capabilities. }\end{array}$ & 4.19 \\
\hline ons are often made intuitively. & 2.34 \\
\hline
\end{tabular}

\subsection{Hypothesis Findings}

It was observed that the data obtained as a result of the research were not distributed normally, and nonparametric tests were used in the analysis of differences. In order to compare the opinions of the participants, Mann Whitney U Test was used for questions with two options and Kruskall Wallis test was used for questions with more than two choices. The significance level $(\alpha)$ was accepted as 0.05 in the evaluation of the analyzes applied. The cumulative result of the hypotheses created within the scope of the research is shown on table 5 .

\section{Table 5. Hypothesis Tests Table}

\begin{tabular}{|l|l|}
\hline $\begin{array}{l}\text { Ha: The knowledge levels of the participants } \\
\text { about strategic management tools differ } \\
\text { according to the variables of sex, age and } \\
\text { educational status. }\end{array}$ & Reject \\
\hline $\begin{array}{l}\text { Hb There is a significant difference in } \\
\text { the views of the participants on strategic } \\
\text { management according to the variables of } \\
\text { gender, age and educational status. }\end{array}$ & Reject \\
\hline $\begin{array}{l}\text { Hc: There is a significant difference in the } \\
\text { opinions of the participants about the } \\
\text { competition between enterprises according } \\
\text { to the variables of age and education level. }\end{array}$ & Accept \\
\hline $\begin{array}{l}\text { Hd: There is a significant difference in the } \\
\text { opinions of the participants about reaching } \\
\text { competing business strategies according to } \\
\text { the variables of gender, age and education } \\
\text { level. }\end{array}$ & Reject \\
\hline $\begin{array}{l}\text { He: There is a significant difference in } \\
\text { the opinions of the participants about the } \\
\text { strategic decisions taken in the business } \\
\text { according to the educational level variable. }\end{array}$ & Accept \\
\hline
\end{tabular}

When Table 5 is examined, it is determined that the participants' level of knowledge about strategic management tools, their views on strategic management and their methods of reaching competitor business strategies do not differ according to variables such as gender, age and education level. However, it has been determined that there are significant differences in the opinions of the participants on the competition between enterprises and their views on the strategic decisions taken in the enterprise, according to their education level. It has been determined that the bachelor's and master's degree participants of views on competition and strategic decisions differ from other education groups. It is seen that the level of education makes a difference in the understanding of competition and in the process of making strategic decisions, and the understanding of strategic management varies according to the education level. 


\section{CONCLUSION}

Today, Small and Medium Enterprises are the cornerstones of the economy and social life. SMEs act as a stabilizer in the country due to their economic and social characteristics. The formation of a balanced and stable economy in the country depends on the system in which SMEs carry out their activities. For this reason, it is important to create suitable conditions for the establishment, development and continuity of SMEs. When today's SMEs are examined, one of the most obvious problems is their inability to maintain their continuity. SMEs should have competitive advantage, differentiate from other businesses and apply strategic management such as foreseeing the future, and develop in line with strategic management in the enterprise in order to make their lives permanent. One of the main objectives of this study is to raise awareness of SME owners or managers on strategic management and to contribute to the survival of SMEs by attracting attention to strategic management and techniques.

As a result of the research, it has been revealed that SMEs operating in Karaman OIZ are lacking in expert managers, and they need management principles and training for activating these principles. It has been observed that the level of strategic awareness and knowledge about strategic management techniques is not sufficient, especially for those whose education level is below the higher education level.

For the business owners and managers, whose opinios were consulted during the study, a meaningful difference emerged between the competition between enterprises and their ages and educational levels and between the strategic decisions made in the business and educational levels. The higher the education level of the participants, the higher the awareness of strategic management is.

When the opinions of the participants on strategic management expressions, competition between businesses, competing business strategies and strategic decisions taken in the company were examined, it was found that they showed high participation in the statements made. Also, it is observed that the participants did not approve of making decisions based on intuitive methods. One of the results obtained in the study is that business owners and managers adopt the opportunity approach and make decisions in line with customer demands.
When the study data are analyzed, it is concluded that SME owners and managers attach importance to profit, increasing customer satisfaction and being accepted by stakeholders, apart from continuity which is the main objective of enterprises.

As a result of the research, it was observed that SME owners and managers have low level of strategic awareness and knowledge of competing businesses. Therefore, it is possible to say that business owners and managers are insufficient in competing business analysis. It is not possible to carry out a useful activity related to strategic management without having strategic awareness. For this reason, first of all, it is important to gain strategic awareness that forms the basis of strategic management. SME managers and owners are expected to increase their knowledge level by being included in the training programs on strategic management in order for SMEs to exhibit the performance expected from them.

\section{REFERENCES}

- ARAGÓN-SÁNCHEZ, A. \&SÁNCHEZ-MARÍN, G. (2005). Strategic Orientation, Management Characteristics, and Performance: A Study of Spanish SMEs, Journal of Small Business Management, 43:3, 287-308. https: / / doi.org/10.1111/j.1540-627X.2005.00138.x

- AYTAR, O. (2019). KOBİ Yöneticilerinin Stratejik Bilinç ve Stratejik Yönetim Algıları Üzerine Bir İçerik Analizi. MANAS Sosyal Araştırmalar Dergisi, 8(4), 3483-3499. https://dx.doi.org/10.33206/ mjss.475473

- BARbOSA, M., CASTAÑEDA-AYARZA, J. A., \& FERREIRA, D. H. L. (2020). Sustainable strategic management (GES): Sustainability in small business. Journal of Cleaner Production, 258, 1-11. https: / / doi.org/10.1016/j.jclepro.2020.120880

- CANSIZ, M. (2008). Türkiye'de KOBÍler ve KOSGEB. DPT Uzmanlık Tezleri, Ankara: Sosyal Sektörler ve Koordinasyon Genel Müdürlüğü Yayın No: 2782

- ÇATAL, M. (2007). Bölgesel Kalkınmada Küçük ve Orta Boy İşletmelerin (Kobi) Rolü. Atatürk Üniversitesi Sosyal Bilimler Enstitüsü Dergisi, 10(2), 333-352.

- DAUDA, Y. A., AKINGBADE, W. A., \& AKINLABI, H. B. (2010). Strategic management practice and corporate performance of selected small business enterprises in Lagos metropolis. International journal of Business and Management, 5(11), 97-105. https: / / doi.org/10.5539/ijbm.v5n11p97

- DİNÇER, Ö. (2007). Stratejik Yönetim ve İşletme Politikası. İstanbul: Alfa Yayınları.

- EMECEN, E. \& ÇIÇEK, H. (2016). KOBİlerin Yönetim ve Organizasyon Sorunları: Burdur İli İmalat Sektöründeki İşletmeler Üzerinde Bir Araştırma. Uluslararası Alanya İşletme Fakültesi Dergisi, 8(1), 141-158.

- EREN, E. (2002). Stratejik Yönetim ve İşletme Politikası. İstanbul: Beta Basım Yayım Dağıtım.

- EREN, E. (2009). Stratejik Yönetim. Eskişehir: Anadolu Üniversitesi Yayınları. 
- GÖNEN, B. (2013). Stratejik Yönetim Dersinin Öğrencilere İş Dünyasında Gerekli Nitelikleri Kazandırma Düzeyi: Ankara Üniversitelerinde Bir Araştırma. Unpublished master thesis, Atılım Univesity Graduate School of Social Sciences, Ankara.

- GÜVERCİN, B. (2008). Rekabetçi Stratejik Yönetim ve Rekabet Edilebilirlik Arasındaki Köprü: Bankacıllk Sektöründe Bir Uygulama. Unpublished master thesis, Ankara Gazi University Graduate School of Social Sciences. Ankara.

- KALAYCI, F. (2017). Küçük ve Orta Ölçekli İşletmelere İhracata Yönelik Verilen Devlet Yardımları: Van Örneği, Türk ve İslam Dünyası Sosyal Araştırmalar Dergisi, 4(15), 239-246.

- KAYA, H. (2014). Stratejik Yönetimde Rekabet Stratejileri Adryaman'da Bulunan KOBI'lere Bir Uygulama. Unpublished master thesis, University of Turkish Aeronautical Association, Institute of Social Science, Ankara.

- KAYAR ÇELIK, B \& AYTAR, O. (2019). Örgütlerde Stratejik Yönetim Farkındalığı: Kırşehir İli Örneği. Avrasya Sosyal ve Ekonomi Araştırmaları Dergisi, 6(8), 129-146.

- KILCI, H. (2013). Küçük ve Orta Büyüklükteki İşletmelerde Stratejik Yönetim Uygulamalart: Tokat İli İmalat KOBİleri Üzerinde Bir Çalışma. Unpublished master thesis, Gazi Osman Paşa University, Institute of Social Science. Tokat.

- KORKMAZ, S. (2003). Küçük ve Orta Ölçekli İşletmelerin Pazarlama ve Finansman Sorunlarının Çözümünde Risk Sermayesinin Kullanılabilirliği Üzerine Bir Araştırma. Gazi Üniversitesi Ticaret ve Turizm Ĕ̈itimi Fakültesi Dergisi, 2, 233-258.

- LUECKE, R. (2005). Strategy: Create and implement the best strategy for your business. Boston: Harvard Business School Publishing.

- MECEK, G. (2020). Küçük ve Orta Büyüklükteki İşletmelerin (KOBİ) Uluslararası Tanımlama Ölçütleri ve Kavramlaştırılması. Ekonomi İşletme Siyaset ve Uluslararası İlişkiler Dergisi (JEBPIR), 6(1), 29-55.

- ÖZBOZKURT, O. (2019). Çağdaş Stratejik Yönetim Mimarisi Üzerine. Avrasya Sosyal ve Ekonomi Araştırmaları Dergisi, 6(4), 67-81.

- SCHMUCK, R. (2020). Strategic management consulting in Hungary. International Journal of Strategic Management and Decision Support Systems in Strategic Management, 25(3), 45-53. https: / / doi. org/10.5937/StraMan2003045S

- SUCU, M.E. (2010). KOBI'lerde Stratejik Yönetim ve Bir Araştırma. Unpublished master thesis, Pamukkale University Graduate School of Social Sciences, Denizli.

- ŞAMILOĞLU, F. \& UYGUN, U. (2012). KOBİlerde Ekonomik Kriz Yönetimi. Mali Çözüm Dergisi, 57, 94-105

- ÜLGEN, H. \& MIRZE, S., K. (2014). İşletmelerde stratejik yönetim. İstanbul: Beta Basım Yayın.

- WILLIAMS JR, R. I., SMITH, A., AARON, J. R., MANLEY, S. C., \& MCDOWELL, W. C. (2020). Small business strategic management practices and performance: A configurational approach. Economic research-Ekonomska istraživanja, 33(1), 2378-2396. https://doi. org/10.1080/1331677X.2019.16774 